\title{
Factors impact on the effectiveness of internal control systems in credit facilities in Binh Thuan province commercial banks
}

\author{
Nguyen Kim Phuoc ${ }^{1 *}$, Vo Thi Que Ngoc ${ }^{1}$ \\ ${ }^{1}$ Ho Chi Minh City Open University, Vietnam \\ *Corresponding author: phuoc.nk@ou.edu.vn
}

\section{ARTICLE INFO}

DOI:10.46223/HCMCOUJS.

econ.en.10.2.582.2020

Received: July $19^{\text {th }}, 2020$

Revised: August $17^{\text {th }}, 2020$

Accepted: August $28^{\text {th }}, 2020$

Keywords:

internal control (COSO

2013), credit operations,

effectiveness, commercial banks
ABSTRACT
The study aims to confirm and measure factors that affect the effectiveness of internal control systems in credit operations in Binh Thuan province commercial banks. According to COSO's internal control framework, there are five components: Control environment, control activities, risk assessment, monitoring, information \& communication. This research adopted the framework by COSO (2013) and the results of expert interviews to offer research models and scales. Data were collected from 300 employees and leaders of 10 commercial banks (30 people/bank) in Binh Thuan province in 2020. The study used a 5-level Likert scale and used SPSS 22.0 software for analysis and interpretation. The results of OLS indicate that all factors: Risk assessment, Risk management, Control environment, Control procedure, Control activities, Credit control, Control capacity, Information, Internal \& External communication influence the effectiveness of internal control systems in credit operations of commercial banks in Binh Thuan province.

\section{Introduction}

Credit activities are the main activities bringing the most profit to Vietnamese commercial banks. However, this is also the riskiest activity. In the context of Vietnam's economic integration, many foreign financial and banking organizations have participated in Vietnam's financial market. Therefore, Vietnamese commercial banks face increasingly fierce competition. To be specific, the operations must conform to international standards as well as the operation efficiency must be further controlled. That requires banks to perform better credit control activities, especially internal control following international standards.

The Basel Committee on Banking Supervision (1998) stated that the significant losses incurred in banking operations stem mainly from the failure of banks to maintain an effective internal control system to prevent blocking or early detection of risk signs, thereby minimizing the damage that may occur to the bank. According to the Basel Committee (1998), an effective internal control system is an important component of the bank's operational management and is a foundation for safe and healthy banking operations.

In the business activities of the bank, credit activities are considered one of the most 
important activities, bringing high revenues and profits to the bank. However, credit risk also has serious impacts on the bank and is arguably the biggest risk in the bank's operations.

In the 1980s, the weakness of internal control was the cause of the collapse of several American companies. The internal control system is crucial to the success or failure of a business or a bank. After the event, enterprises, especially banks, became increasingly interested in the adequacy, effectiveness, and efficiency of the internal control system (Vu, 2006).

On $1^{\text {st }}$ August, 2006, the Governor of the State Bank issued Decision No. 36/2006/QDNHNN on "Regulation on internal inspection and control of credit institutions", replacing Decision 03/1998/QD-NHNN. This decision once again affirms the role of internal control (IC), but the function of IC is not separated from the internal audit.

Commercial banks in Vietnam have already had internal control. However, the effectiveness of the internal control system is low. Recent studies in Vietnam such as Pham (2016), H. P. T. Nguyen (2017), T. L. Nguyen (2018), V. N. T. Truong (2018) \& P. T. H. Truong (2020) have spotted the difference of the IC system in banks. Also, these studies revealed the impacts of Vietnamese commercial goods and the effectiveness of the IC system on the bank's operations (credit risk, bad debt risk, credit quality, and so forth). From such findings, it is noticeable that the commercial banks in Vietnam have not implemented the internal control criteria of COSO (2013).

This study aims to identify and measure the factors affecting the effectiveness of the international standard IC system (COSO, 2013) for the credit activities of Vietnamese commercial banks in the province. Results from this study can help the local authorities propose some recommendations to improve the effectiveness of the IC system of credit activities of Vietnam commercial banks in Binh Thuan province in the coming time.

\section{Theoretical framework}

\subsection{Theories}

The Committee of Sponsoring Organization (COSO) is an anti-fraud research organization in the financial statements (including IC systems) of the US National Council. In 1992, COSO issued a set of guidelines for internal control systems of financial institutions, and in 2013, the set of indicators was updated and revised to ensure conformity with the current environment (Table 1). COSO (2013) introduces 5 items with 17 principles (Table 1) that affect the effectiveness of the IC system that financial institutions need to ensure to minimize the organization's financial risks.

Internal control is defined as plans and coordination of a combination of methods and measurements performed within the entity to protect assets. It is used to check the reliability and accuracy of the accounting data to improve performance and encourage compliance with established management policies (Heier, Dugan, \& Sayers, 2005).

According to COSO (2013), IC is a continuous process and involves many members of the organization (from employees, middle managers, and senior managers) to ensure the operation. The organization's effectiveness complies with regulations and reliable financial reports. In the credit activities of the bank, IC ensures effective credit operations (reducing credit risk, reducing bad debt ratio). Ayagre, Appiah-Gyamerah, and Nartey (2014) claimed that the effectiveness of the bank's IC system depends on whether the bank complies with five components according to COSO (2013) standards.

Internal control systems are the policies, procedures, internal regulations, bank practices, organizational structure, which are established and implemented to achieve the bank's objectives 
and ensure prevention, detection and timely handling of risks occur ( $\mathrm{Vu}, 2006)$. Considering internal control of Vietnam and COSO (2013), there are similarities regarding policies, procedures, information, and control activities to minimize risks during the operations of the bank. However, Vietnamese banks have not mentioned the issue of communication, environmental control, and risk assessment.

According to Mishkin and Eakins (2015), bank credit is the relationship between borrowing and lending in the form of currency with principal and interest repayment between banks and other entities in the economy. Credit is the main activity - not merely the most profitable activity but also the activity that brings the most risks in commercial banks. Many factors affect the credit risk of commercial banks, including internal control. Validity is the result that the user rated good and effective. Thus, the study the effectiveness of IC in credit activities at banks is the study of the effect of the application of the IC system to bring about good effects and reduce risks in credit activities of the bank.

\section{Table 1}

Internal control principles

\begin{tabular}{|c|c|c|c|}
\hline Item & Principles & Item & Principles \\
\hline \multirow{5}{*}{$\begin{array}{c}\text { Control } \\
\text { environment }\end{array}$} & $\begin{array}{l}\text { Demonstrates commitment to } \\
\text { integrity \& ethical } \\
\text { values }\end{array}$ & \multirow{3}{*}{ Control activities } & $\begin{array}{l}\text { Selects and develops } \\
\text { control activities }\end{array}$ \\
\hline & $\begin{array}{l}\text { Exercises oversight } \\
\text { responsibility }\end{array}$ & & $\begin{array}{l}\text { Selects and develops } \\
\text { general controls over } \\
\text { technology }\end{array}$ \\
\hline & $\begin{array}{l}\text { Establishes structure, } \\
\text { authority, \& responsibility }\end{array}$ & & $\begin{array}{l}\text { Deploys through policies } \\
\text { and procedures }\end{array}$ \\
\hline & $\begin{array}{l}\text { Demonstrates commitment to } \\
\text { competence }\end{array}$ & \multirow[b]{2}{*}{ Monitoring } & $\begin{array}{l}\text { Conducts ongoing and/or } \\
\text { separate evaluations }\end{array}$ \\
\hline & Enforces accountability & & $\begin{array}{l}\text { Evaluates and } \\
\text { communicates deficiencies }\end{array}$ \\
\hline \multirow{4}{*}{$\begin{array}{c}\text { Risk } \\
\text { Assessment }\end{array}$} & Specifies suitable objectives & \multirow{4}{*}{$\begin{array}{l}\text { Information \& } \\
\text { communication }\end{array}$} & Uses relevant information \\
\hline & Identifies and analyzes risk & & Communicates internally \\
\hline & Assesses fraud risk & & Communicates externally \\
\hline & $\begin{array}{l}\text { Identifies and analyzes the } \\
\text { significant change }\end{array}$ & & \\
\hline
\end{tabular}

Source: COSO (2013)

In Vietnam, the IC system consists of five components, namely: Control environment, risk management and assessment system, control activities, information systems and information exchange mechanism, information and monitoring mechanism for controlling activities $(\mathrm{Vu}$, 2006). According to this concept, the internal control system of Vietnam has not completely coincided with world standards.

Based on the criteria of COSO, the Basel Committee also provided components to evaluate 
the IC system of the bank (Basel Committee, 1998), to ensure the effectiveness and efficiency of banking operations and enhance the bank's operations safely. Basel is commonly used in Asian countries, while COSO is used by most countries around the world. Therefore, this research applied the theoretical framework of COSO (2013) to propose a research model.

\subsection{Overview of previous studies}

T. L. Nguyen (2018) studied the factors affecting the effectiveness of IC of credit operations at 26 commercial banks in Vietnam based on COSO (2013) standards and previous studies of Vo and Le (2014), Ayagre et al. (2014). Monitoring 250 leaders and employees of 26 commercial banks in Vietnam in 2017. The results showed that factors such as risk monitors, control procedures, communication, and control environment have a positive impact on the validity of IC of credit operations in Vietnam commercial banks.

V. N. T. Truong (2018) used the analysis framework of COSO (2013) and collected data from 10 joint-stock commercial banks in Vietnam (BIDV, VietinBank, Vietcombank, Techcombank, ACB, VPBank, MBB, Maritime Bank, Sacombank \& VIB). Research results show that the factors of IC affecting the credit activities of banks are (ranked by the level of decreasing influence) credit monitoring, communication, environment assessment (separated from control environment), credit risk assessment. Credit control did not reach statistical significance.

Adetiloye, Olokoyo, and Taiwo (2016) looked at issues of IC in four banks of Nigeria. The study used a combination of primary and secondary data. Primary data was collected through a questionnaire used to interview 30 people/ banks (five-point Likert scale). The independent variables are Separation of duties, Monitoring, and Staff qualification (qualification and information technology). As a result, IC is effective against fraud itself, but not all employees are committed to it. All independent variables have a positive impact on the dependent variable, in which the information technology level of employees has the strongest impact on the effectiveness of the IC system (dependent variable).

Ayagre, Appiah-Gyamerah, and Nartey (2014) used the theoretical framework of COSO (2013) to evaluate the IC system of Ghanaian goods. The study used questionnaires (5-level Likert scale) to measure managers' awareness (including audit management) of IC in all banks in Ghana. The results show that the control environment and monitoring system are the two components that have the strongest (positive) impact on the effectiveness of the IC system.

Abiola and Oyewole (2013) focused on studying the impact of IC systems on fraud detection in Nigerian commercial banks. The results of regression analysis (OLS) and correlation analysis showed that the IC system and the ability to detect fraud were positively correlated (statistical significance level of 5\%). Training employees is important to the effectiveness of the IC system and the ability to detect frauds in the bank. Research results of Abiola and Oyewole (2013) are similar to those of Olatunji (2009). However, Olatunji (2009) further found that the process of cash control, clear division of personnel, personnel policy, and recruitment policy also have a strong influence on the IC system.

Sultana and Haque (2011) assessed the effectiveness of controlling six private banks in Bangladesh according to COSO 1992. The results showed that information, compliance level, and reliability of information and communication positively affected the effectiveness of IC in the bank. The research results of Sultana and Haque (2011) were also confirmed by Salehi, Shiri, and Ehsanpour (2013) through survey data of banks in Mellat, Iran. 


\section{Research model, data and research methods}

Research models are recommended according to COSO's 2013 framework about IC, bank IC standards according to Basel Committee (1998) and previous studies such as T. L. Nguyen (2018), Adetiloye et al. (2016). Ayagre et al. (2014), Abiola and Oyewole (2013), Salehi, Shiri and Ehsanpour (2013), Sultana and Haque (2011), Olatunji (2009).

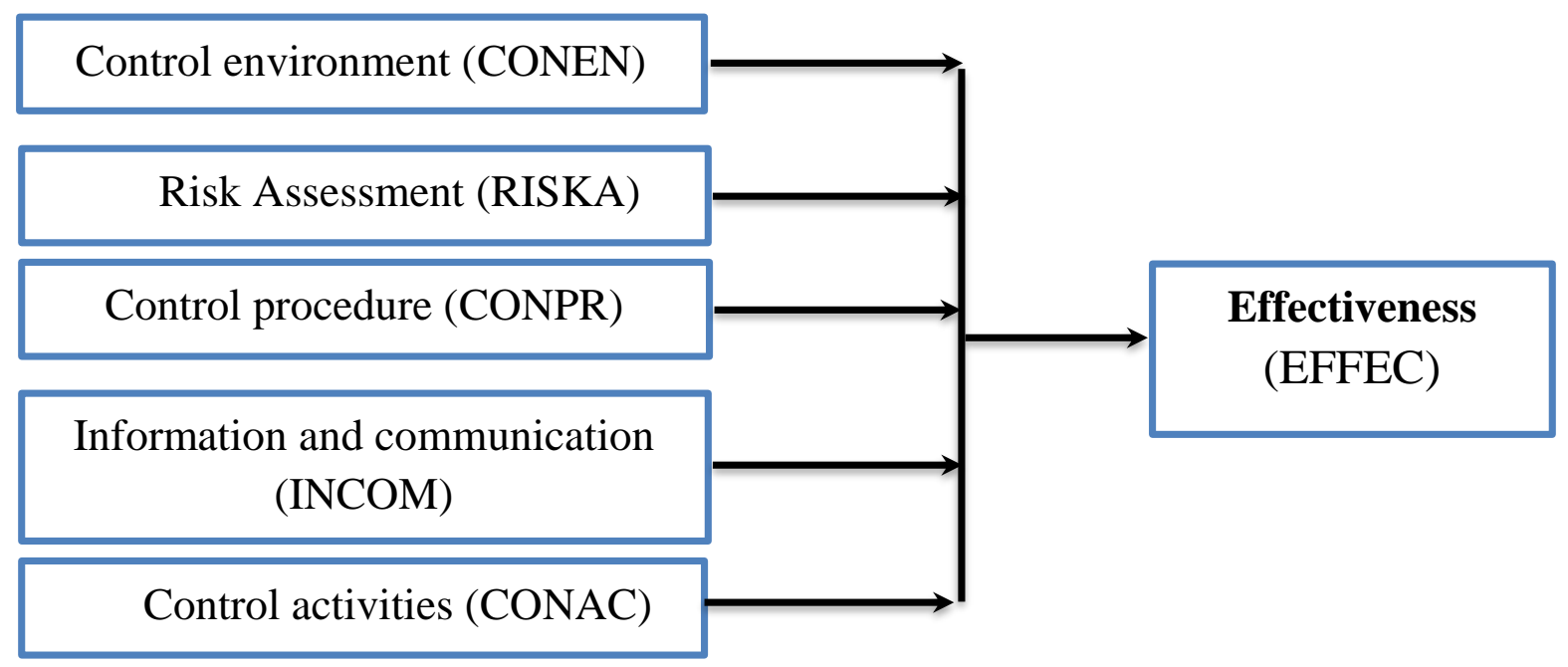

Figure 1. Recommended research model

According to T. L. Nguyen (2018) \& Ayagre et al. (2014), the control environment which demonstrates a commitment to honesty \& ethical compliance, enforcement, and accountability of the staff in the bank affects the effectiveness of internal control. Therefore, we hypothesize as follows $\mathrm{H}_{1}$ : CONEN positive impact on EFFEC.

Activities: identifying, analyzing, and assessing risks that may occur in credit operations are some of the important points that affect the bank's performance. The internal control department must perform these tasks. According to COSO (2013), risk assessment is an important element of the internal control system. Research results by Abiola and Oyewole (2013) \& Ayagre et al. (2014), T. L. Nguyen (2018) have proved that. Based on that, the hypothesis $\mathrm{H}_{2}$ : RISKA positive impact on EFFEC) is proposed.

According to T. L. Nguyen (2018) \& Ayagre et al. (2014), control procedure is related to the process of selecting and implementing policies and procedures to control credit activities. The control procedure has a positive influence on the effectiveness of the IC system in the bank. Therefore, we hypothesize as follow $\mathrm{H}_{3}$ : CONPR positive impact on EFFEC.

Internal and external communication \& information have a significant influence on the performance of organizations. The communication process needs to use appropriate tools and means and it is necessary to control the information for each group of objects (some information is not transmitted outside). According to the research results of Sultana and Haque (2011) \& Adetiloye et al. (2016), information \& communication has a positive influence on the effectiveness of the IC system in the bank. So, we hypothesize as follow $\mathrm{H}_{4}$ : INCOM positive impact on EFFEC.

Research results of Sultana and Haque (2011), T. L. Nguyen (2018) \& Ayagre et al. (2014) have demonstrated, control activities (control of all procedures, pre, during, and post-credit) has important implications for banks. Therefore, we hypothesize as follows $\mathrm{H}_{5}$ : CONAC positive impact on EFFEC. 
The research is done through qualitative and quantitative methods. The method of interviewing 10 experts (with more than 5 years of experience) in credit risk management and IC of 10 commercial banks in Binh Thuan province was implemented to complete the research scale. The completed scale (after experts' comments) was put into use for interviewing $300(\mathrm{n}=300)$ staff (credit specialists), department heads and directors, deputy directors of related departments (staff involves in IC) directly to credit activities of 10 commercial banks in Binh Thuan province (BIDV, AGRIBANK, VIETINBANK, TECHCOMBANK, SACOMBANK, ACB, VCB, SHB, SCB and MB). The study uses a full sampling method (each bank has 30 staff and leaders involved in the internal control of credit operations).

The study uses the 5 point Likert scale and uses OLS (ordinary least square). The data is based on SPSS 22.0 software for analysis: (i) Descriptive statistical; (ii) Cronbach's Alpha; (iii) EFA and (iv) OLS.

\section{Results}

\subsection{Descriptive statistical analysis}

\section{Table 2}

Sample statistics

\begin{tabular}{|l|c|c|}
\hline \multicolumn{1}{|c|}{ Status } & Group & Frequency (\%) \\
\hline \multirow{3}{*}{ Gender } & Male & 55.3 \\
\hline \multirow{4}{*}{ Experience (years) } & Female & 44.7 \\
\cline { 2 - 3 } & $\leq$ 1 year & 12.7 \\
\cline { 2 - 3 } & From 1 - 3 years & 28.3 \\
\cline { 2 - 3 } & Over 3 - 5 years & 26.3 \\
\cline { 2 - 3 } & Over 5 - 7 years & 16.7 \\
\cline { 2 - 3 } Job title & Over 7 years & 16.0 \\
\cline { 2 - 3 } & Staff & 94.3 \\
\cline { 2 - 3 } & Head/ deputy head & 5.3 \\
\cline { 2 - 3 } & Director/ deputy director & .3 \\
\hline
\end{tabular}

Source: Data analysis result of the research

The sample consisted of 300 observations, of which male accounted for over $55 \%$, Female accounted for nearly 45\%. Most interviewees are employees, Head/deputy head and director/deputy director are small. People with experience from over 3 years accounted for nearly $60 \%$ of the sample. With the above analysis results, the distribution research sample is relatively suitable. 


\section{Table 3}

Results of statistical analysis of independent variables

\begin{tabular}{|c|c|c|c|c|c|}
\hline Code & Item & Min & Max & Mean & Std. Dev \\
\hline CONEN1 & $\begin{array}{l}\text { Bank leaders complied with regulations on } \\
\text { credit control at banks }\end{array}$ & 3.00 & 5.00 & 4.12 & .60 \\
\hline CONEN2 & $\begin{array}{l}\text { The bank has a clear credit and recruitment } \\
\text { policy }\end{array}$ & 3.00 & 5.00 & 4.07 & .55 \\
\hline CONEN3 & $\begin{array}{l}\text { The bank has specific and clear plans of } \\
\text { training policies for leaders and employees }\end{array}$ & 3.00 & 5.00 & 4.17 & .63 \\
\hline CONEN4 & $\begin{array}{l}\text { The bank has clear and specific disciplines as } \\
\text { well as policies of salary, bonus }\end{array}$ & 3.00 & 5.00 & 4.21 & .66 \\
\hline CONEN5 & $\begin{array}{l}\text { The bank has specific policies on periodical job } \\
\text { rotation }\end{array}$ & 3.00 & 5.00 & 4.18 & .75 \\
\hline CONEN6 & $\begin{array}{l}\text { The bank has specific regulations and clear } \\
\text { institutionalized written responsibilities of } \\
\text { managers and employees }\end{array}$ & 3.00 & 5.00 & 4.12 & .62 \\
\hline CONEN7 & $\begin{array}{l}\text { The manual on professional ethics is } \\
\text { disseminated periodically }\end{array}$ & 3.00 & 5.00 & 4.15 & .66 \\
\hline CONEN8 & $\begin{array}{l}\text { The handbook of professional ethics is } \\
\text { committed by employees }\end{array}$ & 3.00 & 5.00 & 3.93 & .63 \\
\hline CONEN9 & $\begin{array}{l}\text { IC department performs the responsibility for } \\
\text { controlling credit risk at banks }\end{array}$ & 3.00 & 5.00 & 3.93 & .64 \\
\hline CONEN10 & $\begin{array}{l}\text { Qualification and professional capacity of } \\
\text { internal audit meet internal control } \\
\text { requirements of banks }\end{array}$ & 3.00 & 5.00 & 4.07 & .73 \\
\hline CONEN11 & $\begin{array}{l}\text { Qualifications and professional competence of } \\
\text { the inspection department meet the internal } \\
\text { inspection requirements of the bank }\end{array}$ & 3.00 & 5.00 & 4.06 & .73 \\
\hline RISKA1 & $\begin{array}{l}\text { The credit quality review process is capable of } \\
\text { forecasting changes in the financial situation } \\
\text { and the solvency of customers in advance }\end{array}$ & 2.00 & 5.00 & 3.87 & .71 \\
\hline RISKA2 & $\begin{array}{l}\text { The timeliness of the risk warning information } \\
\text { when there are adverse changes in the business } \\
\text { environment and credit activities }\end{array}$ & 3.00 & 5.00 & 3.93 & .68 \\
\hline RISKA3 & The update of regulations on business lines & 3.00 & 5.00 & 3.97 & .70 \\
\hline RISKA4 & $\begin{array}{l}\text { The update of regulations on credit risk } \\
\text { management }\end{array}$ & 3.00 & 5.00 & 3.98 & .73 \\
\hline RISKA5 & $\begin{array}{l}\text { The flexibility of credit interest rates for } \\
\text { customers based on customer classification } \\
\text { while considering credit extension }\end{array}$ & 3.00 & 5.00 & 4.01 & .70 \\
\hline
\end{tabular}




\begin{tabular}{|c|c|c|c|c|c|}
\hline Code & Item & Min & Max & Mean & Std. Dev \\
\hline RISKA6 & $\begin{array}{l}\text { The bank has early warning criteria for } \\
\text { problematic debt }\end{array}$ & 3.00 & 5.00 & 3.92 & .66 \\
\hline CONPR1 & $\begin{array}{l}\text { Validity of the credit control from the } \\
\text { implementation of internal bank credit process }\end{array}$ & 3.00 & 5.00 & 3.90 & .65 \\
\hline CONPR2 & $\begin{array}{l}\text { The validity of credit control from complying } \\
\text { with internal regulations on credit rating for } \\
\text { corporate customers }\end{array}$ & 3.00 & 5.00 & 3.92 & .68 \\
\hline CONPR3 & $\begin{array}{l}\text { The validity of credit control from complying } \\
\text { with internal regulations on credit rating for } \\
\text { individual customers }\end{array}$ & 3.00 & 5.00 & 3.95 & .66 \\
\hline CONPR4 & $\begin{array}{l}\text { The validity of credit control from complying } \\
\text { with internal regulations on loan security }\end{array}$ & 3.00 & 5.00 & 3.98 & .67 \\
\hline CONPR5 & $\begin{array}{l}\text { The validity of the credit approval mechanism } \\
\text { based on the four-eye principle }\end{array}$ & 3.00 & 5.00 & 3.96 & .64 \\
\hline CONPR6 & $\begin{array}{l}\text { The validity of the automatic debt group } \\
\text { transfer control mechanism is pre-formatted in } \\
\text { the banking information technology system }\end{array}$ & 3.00 & 5.00 & 4.03 & .50 \\
\hline CONPR7 & $\begin{array}{l}\text { The storage of records and documents only } \\
\text { authorized persons to have access to this } \\
\text { information }\end{array}$ & 3.00 & 5.00 & 4.30 & .63 \\
\hline CONPR8 & $\begin{array}{l}\text { The bank takes measures to ensure the safety of } \\
\text { information on computer systems, has a backup } \\
\text { system in case of theft }\end{array}$ & 3.00 & 5.00 & 4.16 & .64 \\
\hline CONPR9 & $\begin{array}{l}\text { The bank regularly checks credit activities } \\
\text { periodically and randomly }\end{array}$ & 3.00 & 5.00 & 4.08 & .63 \\
\hline INCOM1 & $\begin{array}{l}\text { Bank's reporting system is built in a timely, } \\
\text { scientific and right manner }\end{array}$ & 3.00 & 5.00 & 4.01 & .58 \\
\hline INCOM2 & $\begin{array}{l}\text { Bank management is always provided timely } \\
\text { and fully information within the bank about } \\
\text { credit activities }\end{array}$ & 3.00 & 5.00 & 4.09 & .57 \\
\hline INCOM3 & $\begin{array}{l}\text { Bank management is always provided with } \\
\text { timely and sufficient information outside the } \\
\text { bank about credit activities }\end{array}$ & 3.00 & 5.00 & 4.10 & .63 \\
\hline INCOM4 & $\begin{array}{l}\text { The information exchange between levels is } \\
\text { done via intranet }\end{array}$ & 3.00 & 5.00 & 4.30 & .67 \\
\hline INCOM5 & $\begin{array}{l}\text { Banks implement ways to receive customer } \\
\text { comments about violations and errors of } \\
\text { officials and employees (suggestion box, } \\
\text { hotline, customer care ...) }\end{array}$ & 2.00 & 5.00 & 4.15 & .70 \\
\hline
\end{tabular}




\begin{tabular}{|c|c|c|c|c|c|}
\hline Code & Item & Min & $\operatorname{Max}$ & Mean & Std. Dev \\
\hline INCOM6 & $\begin{array}{l}\text { Internal regulations and policies are timely, } \\
\text { clearly, and specifically communicated and } \\
\text { communicated to employees }\end{array}$ & 3.00 & 5.00 & 4.18 & .63 \\
\hline INCOM7 & $\begin{array}{l}\text { Employees need notifying internal regulations } \\
\text { and policies which are presented in the form of } \\
\text { questionnaires and answers on the clear and } \\
\text { specific content of credit control }\end{array}$ & 3.00 & 5.00 & 4.10 & .60 \\
\hline INCOM8 & $\begin{array}{l}\text { Communication of credit risk alerts to leaders } \\
\text { and employees is maintained regularly }\end{array}$ & 3.00 & 5.00 & 4.14 & .59 \\
\hline CONAC1 & $\begin{array}{l}\text { The bank performs supervision throughout the } \\
\text { lending process }\end{array}$ & 3.00 & 5.00 & 4.12 & .60 \\
\hline CONAC2 & $\begin{array}{l}\text { The bank regularly sends collated letters and } \\
\text { polls to clients }\end{array}$ & 2.00 & 5.00 & 3.89 & .72 \\
\hline CONAC3 & $\begin{array}{l}\text { The bank meets customers directly to resolve } \\
\text { complaints, questions and advise customers }\end{array}$ & 2.00 & 5.00 & 4.00 & .68 \\
\hline CONAC4 & $\begin{array}{l}\text { The Bank has timely measures to ensure the } \\
\text { rights of customers }\end{array}$ & 3.00 & 5.00 & 3.92 & .59 \\
\hline CONAC5 & $\begin{array}{l}\text { Quality of credit risk alerts of Internal Audit, } \\
\text { internal inspection after each audit }\end{array}$ & 3.00 & 5.00 & 4.06 & .62 \\
\hline CONAC6 & $\begin{array}{l}\text { Quality of the bank's self-assessment and self- } \\
\text { correction reports on credit activities }\end{array}$ & 3.00 & 5.00 & 4.05 & .71 \\
\hline CONAC7 & $\begin{array}{l}\text { Timeliness of credit risk warning in the bank } \\
\text { of the Credit Management Committee }\end{array}$ & 3.00 & 5.00 & 3.99 & .74 \\
\hline EFFEC1 & $\begin{array}{l}\text { IC systems of banks have a positive impact on } \\
\text { preventing and limiting credit risks }\end{array}$ & 3.00 & 5.00 & 4.00 & .70 \\
\hline EFFEC2 & $\begin{array}{l}\text { The IC system of banks has a positive impact } \\
\text { on improving the effectiveness of credit } \\
\text { operations }\end{array}$ & 3.00 & 5.00 & 4.03 & .69 \\
\hline EFFEC3 & $\begin{array}{l}\text { The level of the implementation of the target of } \\
\text { outstanding credit balance compared to the } \\
\text { plan }\end{array}$ & 3.00 & 5.00 & 3.98 & .72 \\
\hline EFFEC4 & $\begin{array}{l}\text { The level of implementation of the bad debt } \\
\text { target compared to the plan }\end{array}$ & 3.00 & 5.00 & 3.92 & .75 \\
\hline EFFEC5 & $\begin{array}{l}\text { The level of the implementation of the target } \\
\text { interest compared to the plan }\end{array}$ & 3.00 & 5.00 & 3.95 & .75 \\
\hline
\end{tabular}

Source: Data analysis result of the research 


\subsection{Cronbach's Alpha analysis}

The research model has 6 factors with 46 observed variables, of which 41 variables belong to 5 independent variables and 5 dependent variables. All variables have a mean value greater than 3 , Std deviation $\geq 1$ (Table 3). This shows that the level of influence of the factors on the effectiveness of the internal control system in the bank is, according to the interviewees, very high and the opinions are quite similar. The results of assessing the reliability of the scale by Cronbach's Alpha show that (Table 4) all 46 variables have correlated item-total variables $\geq 0.3$ and Cronbach's Alpha $\geq 0.8$. Thus, the scale used in the study is appropriate.

\section{Table 4}

The results of the reliability analysis of the scale

\begin{tabular}{|c|l|c|c|c|c|}
\hline Factor & \multicolumn{1}{|c|}{ Scales } & $\begin{array}{c}\text { N of } \\
\text { Items }\end{array}$ & $\begin{array}{c}\text { Corrected } \\
\text { Item-Total } \\
\text { Correlation } \\
\text { (Minimum) }\end{array}$ & $\begin{array}{c}\text { Corrected } \\
\text { Item-Total } \\
\text { Correlation } \\
\text { (Maximum) }\end{array}$ & $\begin{array}{c}\text { Cronbach's } \\
\text { Alpha }\end{array}$ \\
\hline 1 & COMEN & 11 & .309 & .640 & .830 \\
\hline 2 & RISKA & 6 & .566 & .738 & .849 \\
\hline 3 & CONPR & 9 & .367 & .722 & .855 \\
\hline 4 & INCOM & 8 & .334 & .674 & .816 \\
\hline 5 & CONAC & 7 & .392 & .622 & .796 \\
\hline 6 & EFFEC (Dependent variables) & 5 & .690 & .759 & .856 \\
\hline & Total & 46 & & & \\
\hline
\end{tabular}

Source: Data analysis result of the research

\subsection{Exploratory factor analysis (EFA)}

All 41 independent variables were included in the EFA analysis. The results showed that $\mathrm{KMO}=0.830$, Sig. $=0.000<0.05$, initial Eigenvalues $=1.010$, cumulative $\%=74.246$ with 11 factors. CONEN8, CONEN9, CONPR7, CONPR8, CONPR9, CONAC4, INCOM3, and CONAC4 are 8 removed independent variables because the factor load is not satisfied (Factor loading $<0.5)$.

IC consists of 5 main components (COSO, 2013). However, each study has its characteristics according to the scope and object of the study, so the research results also have certain changes. For example, the research results of Adetiloye et al. (2016) have split the banking staff into two groups (professional and IT level). The research results of Abiola and Oyewole (2013) also challenged the control environment group and finally subdivided it into three groups: hiring policies, training, and employee commitment. Sultana and Haque (2011) divided a group of communication information and control environment into four groups. Therefore, in this study, it is appropriate to dissociate control environment groups from communication information. According to V. N. T. Truong (2018), the control environment group is divided into two separate groups and so are the control activities. Thus, the EFA analysis results of this study have the appropriate group of factors due to the characteristics of the data set. 


\section{Table 5}

The results of EFA (independent variables)

\begin{tabular}{|c|c|c|c|c|c|c|c|c|c|c|c|c|}
\hline \multirow{2}{*}{ Item } & \multirow{2}{*}{$\begin{array}{l}\text { New } \\
\text { group }\end{array}$} & \multicolumn{11}{|c|}{ Component } \\
\hline & & 1 & 2 & 3 & 4 & 5 & 6 & 7 & 8 & 9 & 10 & 11 \\
\hline RISKA6 & \multirow{4}{*}{ RISKA } & .778 & & & & & & & & & & \\
\hline RISKA5 & & .773 & & & & & & & & & & \\
\hline RISKA1 & & .729 & & & & & & & & & & \\
\hline RISKA2 & & .702 & & & & & & & & & & \\
\hline INCOM7 & \multirow{5}{*}{ INFOR } & & .823 & & & & & & & & & \\
\hline INCOM8 & & & .760 & & & & & & & & & \\
\hline INCOM1 & & & .650 & & & & & & & & & \\
\hline INCOM6 & & & .636 & & & & & & & & & \\
\hline INCOM2 & & & .600 & & & & & & & & & \\
\hline CONEN6 & \multirow{4}{*}{ CONEN } & & & .791 & & & & & & & & \\
\hline CONEN7 & & & & .771 & & & & & & & & \\
\hline CONEN2 & & & & .729 & & & & & & & & \\
\hline CONEN1 & & & & .671 & & & & & & & & \\
\hline CONPR2 & \multirow{3}{*}{ CONPR } & & & & .797 & & & & & & & \\
\hline CONPR5 & & & & & .730 & & & & & & & \\
\hline CONPR6 & & & & & .681 & & & & & & & \\
\hline CONEN4 & \multirow{3}{*}{ HRPOL } & & & & & .857 & & & & & & \\
\hline CONEN5 & & & & & & .791 & & & & & & \\
\hline CONEN3 & & & & & & .648 & & & & & & \\
\hline CONAC6 & \multirow{3}{*}{ CONAC } & & & & & & .855 & & & & & \\
\hline CONAC7 & & & & & & & .750 & & & & & \\
\hline CONAC5 & & & & & & & .631 & & & & & \\
\hline RISKA3 & \multirow{2}{*}{ RISKM } & & & & & & & .844 & & & & \\
\hline RISKA4 & & & & & & & & .801 & & & & \\
\hline CONPR4 & \multirow{3}{*}{ CRECO } & & & & & & & & .771 & & & \\
\hline CONPR3 & & & & & & & & & .770 & & & \\
\hline CONPR1 & & & & & & & & & .562 & & & \\
\hline INCOM4 & \multirow{2}{*}{ COMIN } & & & & & & & & & .761 & & \\
\hline INCOM5 & & & & & & & & & & .755 & & \\
\hline CONEN11 & \multirow{2}{*}{ CAPAC } & & & & & & & & & & .837 & \\
\hline CONEN10 & & & & & & & & & & & .832 & \\
\hline CONAC3 & \multirow{2}{*}{ CONEX } & & & & & & & & & & & .857 \\
\hline CONAC2 & & & & & & & & & & & & .805 \\
\hline
\end{tabular}

Extraction Method: Principal Component Analysis; a. Rotation converged in 8 iterations.

Source: Data analysis result of the research 
All 5 observed variables (belong to dependent groups) were put into in the EFA analysis. The analysis results showed that $\mathrm{KMO}=0.789$, Sig. $=0.000<0.05$, initial Eigenvalues $=2.805$, cumulative $\%=70.137$. Variables "EFFEC1" removed (Factor loading $<0.5$ ). Thus, the dependent variable group has four observed variables eligible for regression analysis.

Based on the results of EFA, the research model was revised as follows:

$\mathrm{EFFCE}=\beta_{0}+\beta_{1} \mathrm{RISKA}+\beta_{2} \mathrm{INFOR}+\beta_{3} \mathrm{CONEN}+\beta_{4} \mathrm{CONPR}+\beta_{5} \mathrm{HRPOL}+\beta_{6} \mathrm{CONAC}+$ $\beta_{7} \mathrm{RISKM}+\beta_{8} \mathrm{H} \mathrm{CRECO}+\beta_{9} \mathrm{COMIN}+\beta_{10} \mathrm{CAPAC}+\beta_{11} \mathrm{CONEX}+\varepsilon$

Including: EFFCE (Efffectiveness in credit operation) is a dependent variable; RISKA (risk assessment), INFOR (Information), CONEN (control enviroment), CONOR (control procedure), HRPOL (Human resource policy), CONAC (Control activities), RISKM (Risk management), CRECO (Credit communication), COMIN (Communicates internally), CAPAC (control capacity), COMEX (Communicates externally) are independent variables; $\varepsilon$ is redundancy.

Hypotheses:

H1: RISKA positive impact on EFFEC

H2: INFOR positive impact on EFFEC

H3: CONEN positive impact on EFFEC

H4: CONPR positive impact on EFFEC

H5: HRPOL positive impact on EFFEC

H6: CONAC positive impact on EFFEC

H7: RISKM positive impact on EFFEC

H8: CRECO positive impact on EFFEC

H9: COMIN positive impact on EFFEC

H10: CAPAC positive impact on EFFEC

H11: COMEX positive impact on EFFEC

\subsection{Multivariate regression and testing}

According to Table 6, in regression testing conditions, the "HRPOL" factor is removed because Sig is greater than 0.05 . Ten components were significantly correlated with "Effectiveness in credit operation" with $99 \%$ reliability.

Brooks (2008), $0 \leq \mathrm{R}^{2} \leq 1$, the higher $\mathrm{R}^{2}$ shows, the model used to analyze can explain the variation of the dependent variable as well. In Table 6 , the adjusted $\mathrm{R}^{2}$ of 0.462 means that $46.2 \%$ "Effectiveness in credit operation" change is explained by 10 factors in the model. Thus, the statistically significant assurance model with the tests was conducted, showing a close relationship between the dependent and independent variables. 


\section{Table 6}

Model test results and hypotheses

\begin{tabular}{|c|c|c|c|c|c|}
\hline Hypotheses & Expected & $\begin{array}{l}\text { Record the } \\
\text { regression } \\
\text { result }\end{array}$ & $\begin{array}{c}\text { Standardized } \\
\text { regression } \\
\text { coefficient }\end{array}$ & $\mathbf{P}$ & Test results \\
\hline $\mathrm{H}_{1^{-}}>\mathrm{RISKA}$ to EFFEC & Positive & Positive & $.214 * * *$ & .000 & Accept \\
\hline $\mathrm{H}_{2^{-}}>$INFOR to EFFEC & Positive & Positive & $.160 * * *$ & .000 & Accept \\
\hline $\mathrm{H}_{3^{-}}>\mathrm{CONEN}$ to EFFEC & Positive & Positive & $.073 *$ & .090 & Accept \\
\hline $\mathrm{H}_{4-}>\mathrm{CONPR}$ to EFFEC & Positive & Positive & $.238 * * *$ & .000 & Accept \\
\hline $\mathrm{H}_{5^{-}}>\mathrm{HRPOL}$ to EFFEC & Positive & Positive & -.001 & .987 & Reject \\
\hline $\mathrm{H}_{6^{-}}>\mathrm{CONAC}$ to EFFEC & Positive & Positive & $.462 * * *$ & .000 & Accept \\
\hline $\mathrm{H}_{7->} \mathrm{RISKM}$ to EFFEC & Positive & Positive & $.118 * * *$ & .007 & Accept \\
\hline $\mathrm{H}_{8^{-}}>\mathrm{CRECO}$ to EFFEC & Positive & Positive & $.168 * * *$ & .000 & Accept \\
\hline $\mathrm{H}_{9^{-}}>\mathrm{COMIN}$ to EFFEC & Positive & Positive & $.144 * * *$ & .001 & Accept \\
\hline $\mathrm{H}_{10^{-}}>\mathrm{CAPAC}$ to EFFEC & Positive & Positive & $.186^{* * *}$ & .000 & Accept \\
\hline $\begin{array}{l}\mathrm{H}_{11^{-}}>\mathrm{COMEX} \text { to } \\
\text { EFFEC }\end{array}$ & Positive & Positive & $.131 * * *$ & .003 & Accept \\
\hline \multicolumn{6}{|c|}{ Test results } \\
\hline & \multicolumn{3}{|l|}{$\mathrm{R}^{2}$} & \multicolumn{2}{|c|}{0.679} \\
\hline & \multicolumn{3}{|l|}{$\mathrm{R}^{2}$ square } & \multicolumn{2}{|c|}{0.462} \\
\hline & \multicolumn{3}{|c|}{ Durbin Watson (DW) } & \multicolumn{2}{|c|}{1.842} \\
\hline & \multicolumn{3}{|l|}{$\mathrm{F}(\operatorname{sig})$} & \multicolumn{2}{|c|}{$22.447(0.000)$} \\
\hline
\end{tabular}

Note: $* \mathrm{p}<0.1 . * * \mathrm{p}<0.05 ; * * * \mathrm{p}<0.01$

Source: Data analysis result of the research

The DW statisticlies in the range $0-4$, a value of 2 or nearly 2 indicates that there is no first-order autocorrelation (Field, 2009). An acceptable range is $1.5<\mathrm{DW}<2.5$, this is also the standard value we use commonly today (Qiao, 2011). With F=22.447 (F-statistic (prob) = 0.000) $\& \mathrm{DW}=1.842$ (Table 7), it can be specified that the given model matches with the data $(99 \%$ reliability). Chart Histogram for the average balance value is $-7.29 \mathrm{E}-17$ and the regular period is 0.983 , so the dependencies variable has standard distribution. 
Table 7

Coefficients

\begin{tabular}{|l|c|c|c|c|c|c|c|}
\hline \multirow{2}{*}{ Model } & \multicolumn{2}{|c|}{$\begin{array}{c}\text { Unstandardized } \\
\text { Coefficients }\end{array}$} & $\begin{array}{c}\text { Standar- } \\
\text { dized } \\
\text { Coefficients }\end{array}$ & \multirow{2}{*}{$\mathbf{t}$} & \multicolumn{2}{c|}{ Sig. } & \multicolumn{2}{c|}{$\begin{array}{c}\text { Collinearity } \\
\text { Statistics }\end{array}$} \\
\cline { 2 - 8 } & B & Std. Error & Beta & & & Tolerance & VIF \\
\hline Constant & $2.438 \mathrm{E}-16$ & .043 & & .000 & 1.000 & & \\
\hline RISKA & $.214 * * *$ & .043 & .214 & 4.951 & .000 & 1.000 & 1.000 \\
\hline INFOR & $.160 * * *$ & .043 & .160 & 3.693 & .000 & 1.000 & 1.000 \\
\hline CONEN & $.073 *$ & .043 & .073 & 1.699 & .090 & 1.000 & 1.000 \\
\hline CONPR & $.238 * * *$ & .043 & .238 & 5.504 & .000 & 1.000 & 1.000 \\
\hline HRPOL & -.001 & .043 & -.001 & -.017 & .987 & 1.000 & 1.000 \\
\hline CONAC & $.462 * * *$ & .043 & .462 & 10.688 & .000 & 1.000 & 1.000 \\
\hline RISKM & $.118 * * *$ & .043 & .118 & 2.725 & .007 & 1.000 & 1.000 \\
\hline CRECO & $.168 * * *$ & .043 & .168 & 3.895 & .000 & 1.000 & 1.000 \\
\hline COMIN & $.144 * * *$ & .043 & .144 & 3.335 & .001 & 1.000 & 1.000 \\
\hline CAPAC & $.186 * * *$ & .043 & .186 & 4.304 & .000 & 1.000 & 1.000 \\
\hline COMEX & $.131 * * *$ & .043 & .131 & 3.019 & .003 & 1.000 & 1.000 \\
\hline
\end{tabular}

Note: $* \mathrm{p}<0.1 . * * \mathrm{p}<0.05 ; * * * \mathrm{p}<0.01$

Source: Data analysis result of the research

According to the regression results (Table 7), there are 10 independent groups of variables that positively impact the dependent variable, only "HRPOL" has not found signs of impact on the dependent variable. Independent groups explanation for $46.2 \%$ of the variation in the dependent variable. According to Hair, Sarstedt, Pieper, and Ringle (2012), The study uses the method of saving factors and regression of all independent factors, so this result shows the correlation between the independent variables has been reduced (VIF \& tolerance equal 1.0).

\section{Discussion}

Factor "RISKA" has $\mathrm{B}=0.214$ (positive sign) và $\mathrm{Sig} .=0.000$. This result shows that the factor "RISKA" has a positive impact on "EFFEC". This result also coincides with the results of the study T. L. Nguyen (2018) \& Ayagre et al. (2014). As such, the credit quality control process, the timeliness of credit information, the early warning criteria for problem debts, and the degree of interest rate flexibility in each customer group are meaningful to the validity of the IC system.

Factor "INFOR" has coefficients $\mathrm{B}=0.160$ (positive sign) và Sig. $=0.000$. This result shows that the factor "INFOR" has a positive impact on "EFFEC". This result also coincides with the results of the study Sultana and Haque (2011). The regulations, policies, the credit information should be disseminated in writing to each employee in the bank, ensuring timely, complete, and accurate credit, especially the credit risk warning system. use. All this has a positive effect on the effectiveness of the internal control system. 
Factor "CONEN" has coefficients $B=0.073$ (positive sign) và Sig. $=0.090$. This result shows that factor "CONNE" has a positive impact on "EFFEC". This result is the same with the results of the study T. L. Nguyen (2018) \& Ayagre et al. (2014). This is the group with the shortest regression coefficient, which means that the weakest influence among the ten factors has a positive effect on the dependent variable.

Factor "CONPR" has coefficients $\mathrm{B}=0.238$ (positive sign) và Sig. $=0.000$. This result shows that factor "CONPR" has a positive impact on "EFFEC". This result also coincides with the results of the study in a way that factor "CONEN" has coefficients $\mathrm{B}=0.073$ (positive sign) và Sig. $=0.090$. This result shows that factor "CONNE" has a positive impact on "EFFEC". This result is the same as the results of the study Sultana and Haque (2011). The control procedure positively influences (ranked second) on the effectiveness of the internal control system in the bank.

Factor "CONAC" has coefficients $\mathrm{B}=0.426$ (positive sign) và Sig. $=0.000$. This is the group with the highest regression coefficient, which means that the strongest among the ten groups has a positive effect on the dependent variable. This result also coincides with the results of the study by T. L. Nguyen (2018) \& Ayagre et al. (2014). As such, the Credit Management Committee has an active role in issuing risk alerts through self-assessment and self-correcting reports. In particular, the quality of the report is important to the effectiveness of the credit-control system.

CRECO have regression coefficients of $0.168(\mathrm{p}=0.000)$. This research result is consistent with the research results of Ayagre et al. (2014) but different from V. N. T. Truong (2018). This shows that the level of credit activity control affects the effectiveness of the IC system. Sometimes this may also be due to the degree of perceived importance of each employee in the implementation of the credit control.

Factor COMIN \& COMEX have regression coefficients of $0.144 \& 0.131$ (With $1 \%$ significance level). This result also coincides with the results of the study Adetiloye et al. (2016) $\&$ Sultana and Haque (2011). These are two groups separated from the media information group (COSO, 2013). This result reflects the reality in Vietnamese banks, the information is divided into two groups (inside and outside) to ensure internal information is leaked. This is entirely appropriate because banks need to control information well to avoid misinformation.

The remaining five factors: RISKM \& CAPAC have regression coefficients of 0.118 \& 0.186 (With $1 \%$ significance level). This result also coincides with the results of the study Ayagre et al. (2014), Abiola and Oyewole (2013). The results of the study showed that the credit risk management system and the capacity of the internal control team are quite important as both have a significant impact on the effectiveness of the credit in banks. Indeed, a bank has good processes, regulations, and policies, but if the enforcement team is not capable of implementing and lacking in professional ethics, the effectiveness of the control system will not be achieved.

\section{Conclusion and recommendations}

\subsection{Conclusion}

The research model consists of five groups of factors (with 41 independent variables) that affect the effectiveness in credit operation in 10 commercial banks in Binh Thuan province. The scale reliability test results show that the scale of measurement used to ensure the reliability of the evidence is that no observable variable is eliminated. So, the scale used in the study is consistent, ensuring reliability. The results of linear regression analysis show that there are 10/11 groups of factors that have positive impacts on the dependent variable, in which the "CONAC" has the 
strongest impact, followed by "CONPR" and "RISKA". Based on the research results, the article gives some recommendations to improve the effectiveness of the internal control of credit activities for commercial banks in Binh Thuan province.

\subsection{Recommendations}

Control environment: The Bank should disseminate its ethical handbook periodically to all employees and leaders in the bank, ensuring that everyone obeys the regulations on credit control at banks. row. All regulations must be institutionalized in writing and clearly define the functions and duties of each person and each division in the bank.

Information and communication (internal and external): The Bank needs to implement the information and communication activities on credit activities, credit information (regulations, rules, processes, policies, etc.) properly to all stakeholders including inside and outside the bank (employees, customers, partners) to ensure that stakeholders understand and comply with credit control regulations.

Control capacity: The Bank should regularly train and update internal control regulations (including industry regulations, credit risk management, credit policies, etc.) to serve each individual and bank member. This must be done at the beginning of staff recruitment and repeated periodically to ensure that employees are professionally qualified to meet the requirements of internal credit control.

Credit risk control and management: Currently, banks in Vietnam have a credit risk warning system; however, they need to review, update and adjust regularly according to regulations of the law, to ensure timely credit risk warning information to relevant departments. The Bank always ensures to comply with the "four eyes" rule when approving credit as well as control activities before, during, and after granting credit. At the same time, banks need to comply with credit rating regulations (including individual and corporate customers).

Control activities and control process: The Bank must ensure that all credit activities are implemented by the set credit procedures, not for any reason, which violates the regulations. It must train personnel to communicate regularly with customers, ensuring that customer information is updated promptly and accurately. The debt reconciliation section with customers' needs to be done periodically and according to different information, channels to ensure a scientific basis for comparison and examination.

The research results have contributed to highlighting the importance of the effectiveness of the IC system on credit operations at commercial banks. This also contributes to the increase in credit performance, reduction of bad debts in banks in general, and the scientific premise for bank administrators to further promote the application of internal control under COSO (2013) in banking activities, especially credit activities. In addition, the research results also show that the analysis framework of COSO (2013) is appropriate, but researchers need to adjust the research model accordingly, especially the need to separate the control and information environment groups along with communication into groups according to the specific characteristics of each subject and scope of the study.

This study was conducted only among 10 commercial banks in Binh Thuan province. However, due to the limited sample (30 samples/bank), it is not possible to compare banks. This is an important premise to expand the scope and directions of research for the next research. 


\section{References}

Abiola, I., \& Oyewole, A. T. (2013). Internal control system on fraud detection: Nigeria experience. Journal of Accounting and Finance, 13(5), 141-152.

Adetiloye, K. A., Olokoyo, F. O., \& Taiwo, J. N. (2016). Fraud prevention and internal control in the Nigerian banking system. International Journal of Economics and Financial, 6(3), 1172-1179.

Ayagre, P., Appiah-Gyamerah, I., \& Nartey, J. (2014). The effectiveness of internal control systems of banks. The case of Ghanaian banks. International Journal of Accounting and Financial Reporting, 4(2), 377-389. doi:10.5296/ijafr.v4i2.6432

Basel Committee. (1998). Framework for internal control systems in banking organization. Retrieved May 10, 2020, from https://www.bis.org/publ/bcbs40.htm

Brooks, C. (2008). Introductory econometrics for finance (2nd ed.). Cambridge, UK: Cambridge University Press.

COSO. (2013). Internal control - Integrated framework: Executive summary. Retrieved May 20, 2020, from https://www.coso.org/Documents/COSO-CROWE-COSO-Internal-ControlIntegrated-Framework.pdf

Field, A. P. (2009). Discovering statistics using SPSS (3rd ed.). London, UK: Sage.

Hair, J. F., Sarstedt, M., Pieper, T. M., \& Ringle, C. R. (2012). The use of partial least squares structural equation modeling in strategic management research: A review of past practices and recommendations for future applications. Long Range Planning, 45(5/6), 320-340. doi:10.1016/j.lrp.2012.09.008

Heier, J. R., Dugan, M. T., \& Sayers, D. L. (2005). A century of debate for internal controls and their assessment: A study of reactive evolution. Accounting History, 10(3), 39-70. doi:10.1177/103237320501000303

Mishkin, F. S., \& Eakins, S. G. (2015). Financial markets and institutions (8th ed.). Upper Saddle River, NJ: Pearson.

Nguyen, H. P. T. (2017). Kiểm soát nội bộ theo COSO 2013 và mối quan hệ với hiệu quả hoạt dộng của các doanh nghiệp [Review of internal control according to COSO 2013]. Retrieved April 15, 2020, from http://www.hoiketoanhcm.org.vn/vn/trao-doi/kiem-soatnoi-bo-theo-coso-2013-va-moi-quan-he-voi-hieu-qua-hoat-dong-cua-cac-doanh-nghiep/.

Nguyen, T. L. (2018). Nhân tố ảnh hưởng đến tính hiệu lực của hệ thống kiểm soát nội bộ trong hoạt động tín dụng tại ngân hành thương mại Việt Nam [Review of factors impact on the effectiveness of internal control systems in credit operation in Vietnam commercial banks]. Science of Journal Ho Chi Minh City Open University, 63(6), 105-121.

Olatunji, O. C. (2009). Impact of internal control system in banking sector in Nigeria. Pakistan Journal of Social Sciences, 6(4), 181-189.

Pham, T. T. (2016). Đánh giá hệ thống kiểm soát nội bộ của ngân hàng thuoong mại Việt Nam và môt số khuyến nghị [Review of the internal control system of commercial banks in Vietnam and some recommendations]. Retrieved May 20, 2020, from Tạp chí Ngân hàng website: http://tapchinganhang.com.vn/danh-gia-he-thong-kiem-soat-noi-bo-cua-ngan-hangthuong-mai-viet-nam-va-mot-so-khuyen-nghi.htm 
Qiao, Y. (2011). Instertate fiscal disparities in America (2th ed.). New York and London: Routledge.

Salehi, M., Shiri, M. M., \& Ehsanpour, F. (2013). Effectiveness of internal control in the banking sector: Evidence from bank Mellat, Iran. IUP Journal of Bank Management, 12(1), 23-34.

State Bank. (1998). Quyết định Số 03/1998/QD-NHNN ban hành quy chế mẫu về tổ chức và hoạt động kiểm tra, kiểm toán nội bộ trong các tổ chức tín dụng hoạt động tại Việt Nam [Decision No. 03/1998 / QD-NHNN of January 3, 1998 of the Governor of the State Bank, promulgating the Model Regulation on internal inspection, audit organization in operating credit institutions activities in Vietnam]. Retrieved April 20, 2020, from https://thuvienphapluat.vn/van-ban/tien-te-ngan-hang/Quyet-dinh-03-1998-QD-NHNN3Quy-che-mau-ve-to-chuc-hoat-dong-kiem-tra-kiem-toan-noi-bo-trong-cac-to-chuc-tindung-hoat-dong-tai-Viet-Nam-41224.aspx

State Bank. (2006). Quyết định Số No. 36/2006/QD-NHNN quyết định ban hành quy chế kiểm tra, kiểm soát nội bộ của tổ chức tín dụng [Decision No. 36/2006/QD-NHNN of August 1, 2006, of the Governor of the State Bank, promulgating the Regulation on internal inspection and control of credit institutions]. Retrieved April 25, 2020, from

https://thuvienphapluat.vn/van-ban/tien-te-ngan-hang/Quyet-dinh-36-2006-QD-NHNNQuy-che-kiem-tra-kiem-soat-noi-bo-to-chuc-tin-dung-13564.aspx

Sultana, R., \& Haque, M. E. (2011). Evaluation of internal control structure: Evidence from six listed banks in Bangladesh. ASA University Review, 5(1), 69-81.

Truong, P. T. H. (2020). Hệ thống kiểm soát nội bộ hoạt động tín dụng cá nhân tại các ngân hàng thương mại cổ phần [Internal control system of individual credit operations at joint stock commercial banks]. Retrieved April 25, 2020, from Tạp chí Tài chính website: http://tapchitaichinh.vn/ke-toan-kiem-toan/he-thong-kiem-soat-noi-bo-hoat-dong-tindung-ca-nhan-tai-cac-ngan-hang-thuong-mai-co-phan-318153.html

Truong, V. N. T. (2018). Yếu tố ảnh hưởng đến kiểm soát nội bộ hoạt động tín dụng tại ngân hàng thuoong mại cổ phần [Factors affecting internal control of credit activities at joint-stock commercial banks]. Retrieved April 25, 2020, from Tạp chí Tài chính website: http://tapchitaichinh.vn/nghien-cuu-trao-doi/nghien-cuu-dieu-tra/yeu-to-anh-huong-denkiem-soat-noi-bo-hoat-dong-tin-dung-tai-ngan-hang-thuong-mai-co-phan-137761.html

Vo, T. H. N., \& Le, T. T. H. (2014). Hoàn thiện hệ thống kiểm khoát nội bộ của các ngân hàng thương mại Việt Nam theo mô hình COSO [Completing the internal control system of commercial banks in Vietnam with the COSO model]. Banking Journal, 4, 22-27. Retrieved April 25, 2020, from http://lib.hcmulaw.edu.vn/opac/WShowDetail.aspx?intItemID= 40759

Vu, N. T. (2006). Hệ thống kiểm soát nội bộ của một ngân hàng hiện đại [Internal control system of a modern bank]. Retrieved April 20, 2020, from https://www.sbv.gov.vn/webcenter/portal/vi/menu/rm/apph/tcnh/tcnh_chitiet?leftWidth= $20 \% 25 \&$ showFooter $=$ false $\&$ showHeader $=$ false $\&$ dDocName $=$ CNTHWEBAP011625222 $17 \&$ rightWidth $=0 \% 25 \&$ centerWidth $=80 \% 25 \&$ afrLoop $=688602401459628 \# \% 40 \% 3 \mathrm{~F}$ _a frLoop\%3D688602401459628\%26centerWidth\%3D80\%2525\%26dDocName\%3DCNT HWEBAP01162522217\%26leftWidth\%3D20\%2525\%26rightWidth\%3D0\%2525\%26sh owFooter\%3Dfalse\%26showHeader\%3Dfalse\%26_adf.ctrl-state\%3Drm53yxfzv_100 